\title{
Hubungan Antara Tindakan Bullying dengan Prestasi Belajar Anak Korban Bullying pada Tingkat Sekolah Dasar
}

\author{
Ida Ayu Surya Dwipayanti dan Komang Rahayu Indrawati \\ Program Studi Psikologi, Fakultas Kedokteran, Universitas Udayana \\ iasuryadwipayanti@yahoo.com
}

\begin{abstract}
Abstrak
Tindak kekerasan di sekolah semakin marak terjadi dewasa ini dilihat dari semakin banyaknya pemberitaan tentang tindak kekerasan tersebut di media cetak maupun di layar televisi. Salah satu contoh tindak kekerasan yang terjadi di sekolah adalah bullying. Korban bullying memiliki penyesuaian sosial yang buruk sehingga membuat korban merasa takut ke sekolah bahkan tidak mau sekolah, menarik diri dari pergaulan, sehingga nantinya akan berdampak pada prestasi belajar korban bullying. Penelitian ini bertujuan untuk mengetahui apakah terdapat hubungan antara tindakan bullying dengan prestasi belajar.
\end{abstract}

Penelitian ini merupakan penelitian kuantitatif yang berlokasi di Kabupaten Badung, Kabupaten Gianyar dan Kota Denpasar. Jumlah sampel yang digunakan dalam penelitian ini berjumlah 176 orang dengan kriteria inklusi yaitu merupakan anak Sekolah Dasar yang sedang duduk di kelas 4. 5 dan 6, dan merupakan anak korban bullying. Metode pengambilan sampel yang digunakan adalah cluster sampling. Metode pengumpulan data yang digunakan adalah satu kuisioner yang mengukur tindakan bullying yang dialami oleh korban bullying (validitas 0.204 sampai 0.646 dan reliabilitas 0.926) dan nilai rapor semester ganjil yang diperoleh oleh korban bullying.

Metode analisis data yang digunakan adalah analisis regresi linier sederhana. Berdasarkan hasil analisis statistik diperoleh hasil $\mathrm{r}=-0.779$ dan $\mathrm{P}=0.000$ ( $\mathrm{P}$ lebih kecil dari 0.05 ) yang artinya ada hubungan negatif antara tindakan bullying dengan prestasi belajar anak korban bullying pada tingkat Sekolah Dasar. Anak korban bullying akan mengalami kesulitan dalam bergaul, merasa takut datang ke sekolah sehingga absensi mereka tinggi dan tertinggal pelajaran, dan mengalami kesulitan berkonsentrasi dalam mengikuti pelajaran sehingga akan berdampak pada prestasi belajarnya. Hasil penelitian ini juga menunjukkan bahwa terdapat perbedaan bentuk tindakan bullying yang dialami oleh korban laki-laki dan perempuan.

Kata kunci : tindakan bullying, prestasi belajar, anak sekolah dasar

\begin{abstract}
Violence action in school is getting widespreadly happened nowadays as can be seen from the growing number of news coverage about the acts of violence in newspaper or television. One example of acts of violence occurring in school is bullying. Bullying victim have a bad social adjustment so that it makes victim feel afraid to go to school even worse they don't want to go at all, secede their selves out from the society, therefore later will be impact to academic achievement of the bullying victim. The aim of this study is to understand whether there is any correlation between bullying action and academic achievement.
\end{abstract}

This study is a quantitative research located in Badung Regency, Gianyar Regency and Denpasar City. Samples used in this study are 176 within clusion criteria those are elementary school students on grade 4th, 5th, and 6th, and are bullying victim. The sampling method is cluster sampling. Data collection method is questionnaire which measure bullying action that happened to bullying victim (validity is around 0.204 to 0.646 and its reliability is 0.926 ) and the report score of uneven semester from bullying victim.

The analysis method is simple linear regression. From the statistic result the score of $r=-0.779$ and $p=0.000$ (p less than 0.05 ) which means there is a negative correlation between bullying action and academic achievement of bullying victim at the elementary school level. The bullying victims will have trouble in social activities, feeling afraid of school that causes a high frequency of absent and can't studying well, and have a trouble in concentration of study. It will impact to the academic achievement. The result of this study is show that there is a difference of bullying action to boys and girls.

Keywords : bullying action, academic achievement, elementary school student 


\section{LATAR BELAKANG}

Tindak kekerasan di sekolah semakin marak terjadi dewasa ini. Hal tersebut dibuktikan dengan semakin banyaknya pemberitaan tentang tindak kekerasan tersebut di media cetak maupun di layar televisi. Salah satu situs berita mengabarkan bahwa pada tahun 2012 masyarakat dikejutkan dengan pemberitaan tentang tawuran pelajar yang terjadi di Jakarta Selatan antara SMAN 6 dan SMAN 70 yang mengakibatkan tewasnya seorang siswa yang berasal dari SMAN 6 Jakarta (Anonim, 2012).

Contoh lain dari tindak kekerasan atau penganiayaan di sekolah adalah bullying. Bullying merupakan suatu istilah asing yang dalam bahasa Indonesia memiliki arti sebagai perundungan. Namun peneliti memilih menggunakan bullying karena istilah ini lebih dikenal di masyarakat dibandingkan dengan istilah perundungan. Terdapat beberapa tokoh yang mendefinisikan tentang bullying sebagai perilaku agresif yang dilakukan secara berulang-ulang baik fisik, verbal maupun psikologis dan biasanya terjadi ketidakseimbangan kekuasaan antara pelaku maupun korban (Rigby, 2007; Alika, 2012; Glew, Rivara \& Freudtner, 2000; Sampson, 2012; Wiyani, 2012). Namun definisi bullying menurut Glew, Rivara dan Freudtner (2000) hanya mengungkapkan bahwa bullying bentuk agresi dan tidak menjelaskan dengan jelas tentang bentuk agresi yang dimaksudkan.

Sampson (2012) dan Riauskina (dalam Christin, 2009) menjelaskan tindakan bullying ditujukan kepada korban yang tidak mampu membela dirinya sendiri, padahal tidak semua korban bullying tidak mampu membela dirinya. Sedangkan Rigby (2007) dan Alika (2012) tidak memfokuskan definisi bullying pada korban yang tidak mampu membela dirinya sediri. Oleh karena itu peneliti memfokuskan definisi bullying berdasarkan definisi yang dikemukakan oleh Rigby (2007) dan Alika (2012) yaitu tindakan menekan atau mengintimidasi anak lain baik secara fisik maupun verbal dan biasanya terjadi ketidakseimbangan kekuasaan diantara pelaku dan korban bullying. Tindakan bullying dalam penelitian ini dilakukan oleh senior yang merasa lebih berkuasa kepada juniornya atau seorang atau sekelompok orang yang merasa lebih berkuasa kepada seorang yang lebih lemah.

Menurut salah satu situs berita, tindak kekerasan atau penganiayaan (bullying) sering kali terjadi pada Masa Orientasi Siswa (Rmol, 2012). Situs pemberitaan lainnya mengatakan bahwa terdapat beberapa kasus tindakan bullying yang dilancarkan pada Masa Orientasi Siswa, yang mana tindakan bullying sendiri biasanya dilakukan oleh senior kepada juniornya. Seperti yang terjadi pada siswa A yang bersekolah di SMA Katolik Don Bosco Jakarta Selatan yang mengalami tindakan bullying yang dilakukan oleh kakak kelasnya. Hasil visum menyatakan bahwa terdapat beberapa luka pukulan di tubuh korban dan terdapat beberapa sulutan rokok di tubuh korban yang ternyata pelakunya adalah 18 orang siswa kelas XII (Down, 2012). Berdasarkan beberapa kasus yang terjadi tindakan bullying sering kali terjadi di dunia sekolah.

Berdasarkan wawancara awal yang dilakukan oleh peneliti kepada beberapa guru Sekolah Dasar khususnya yang berada di Kabupaten Badung, Kabupaten Gianyar dan Kota Denpasar, diperoleh hasil bahwa delapan dari sepuluh guru mengetahui bahwa siswanya kerap terlibat dalam tindakan bullying baik itu sebagai pelaku maupun sebagai korban. Bahkan beberapa di ataranya sampai terlibat kontak fisik dan menimbulkan luka fisik pada kedua belah pihak (FN2L8).

Field (2007) membagi tipe-tipe tindakan bullying menjadi teasing (sindiran), exclusion (pengeluaran), physical (fisik) dan harassment (gangguan). Contoh dari teasing (sindiran) yaitu mengejek, menghina, melecehkan, meneriaki, mengganggu korban melalui alat komunikasi. Exclusion (pengeluaran) berkaitan dengan mengucilkan korban secara sosial seperti mengeluarkan korban dari grup teman sebaya, tidak mengikutsertakan korban dalam percakapan, dan tidak mengikutsertakan korban dalam permainan. Contoh dari physical (fisik) seperti memukul, menendang, menjambak, mendorong, mengganggu dan merusak barang milik korban. Harassment (gangguan) berkaitan dengan pernyataan yang bersifat mengganggu dan menyerang tentang masalah seksual, jenis kelamin, ras, agama, dan kebangsaan.

Olewus (dalam Wiyani, 2012) membedakan tipe tindakan bullying hanya dengan membaginya menjadi dua kelompok, sehingga menurut peneliti hal tersebut belum cukup untuk menjelaskan seberapa jauh batasan-batasan antara tipe tindakan bullying satu dengan yang lainnya. Begitu juga tipe tindakan bullying menurut Riauskina, Djuwita, dan Soesetio (dalam Wiyani, 2012) yang menurut peneliti belum mencakup semua tipe tindakan bullying yang terjadi di kalangan korban bullying pada tingkat Sekolah Dasar. Oleh karena itu peneliti memfokuskan tipe tindakan bullying yang dikemukakan oleh Field (2007) karena aspek dan indikator yang dipaparkan oleh Field (2007) sangat jelas dan relevan dengan konteks yang umum terjadi dan hal ini yang penelitian jadikan acuan dalam melihat hubungan tindakan bullying dengan prestasi belajar.

Wiyani (2012) mengungkapkan tindakan bullying cenderung disepelekan atau kurang diperhatikan dalam kehidupan sehari-hari. Masih banyak yang menganggap bahwa bullying tidak berbahaya, padahal sebenarnya bullying dapat memberikan dampak negatif bagi korbannya. Pada tahun 2009, Roy Aditya Perkasa (16 tahun) siswa Sekolah Menengah Atas Negeri 16 Surabaya tewas setelah mengikuti masa orientasi siswa baru di sekolah dan menurut dokter forensik Rumah Sakit Dr. Soetomo Surabaya diduga Roy Aditya Perkasa meninggal lantaran kekurangan oksigen 
(Down, 2012). Riyana (2009) mengemukakan terjadinya kasus lain seperti yang dialami oleh Putri (10 tahun). Putri yang saat ini duduk di bangku kelas 4 Sekolah Dasar ini mengalami kesakitan pada bagian dadanya. Hal ini dikarenakan Putri ditendang oleh salah satu temannya di kelas. Kejadian ini berlangsung ketika jam istirahat, pada saat itu siswa dan siswi Sekolah Dasar yang berada di wilayah Umbulharjo sedang bercanda di dalam kelas. Namun ternyata kegiatan tersebut malah menimbulkan pertengkaran karena salah satu teman laki-laki Putri merasa tidak nyaman dengan hal tersebut. Pelaku kemudian secara spontan menendang Putri yang pada saat itu berada di dekatnya, namun Putri tidak melawan karena pelaku terkenal sebagai anak yang bandel. Putri juga merasa takut untuk melaporkannya kepada guru. Kejadian tersebut terulang kembali dan korbannya pun bertambah yaitu lebih dari satu orang. Akhirnya kejadian tersebut dilaporkan dan pelaku kemudian dipanggil oleh kepala sekolah.

Pada kasus bullying, korban bullying mengalami masalah fisik maupun psikologis (Christin, 2009). Hal tersebut diperkuat oleh Srabstein dkk., (dalam Santrock, 2009) yang mengungkapkan bahwa individu yang menjadi korban bullying akan mengalami masalah kesehatan seperti sakit kepala, pusing, sulit tidur, dan kecemasan. Menurut Trigg (dalam Siswati \& Widiyanti, 2009) korban bullying memiliki penyesuaian sosial yang buruk, hal ini menyebabkan korban merasa takut ke sekolah sehingga tidak jarang korban tidak mau pergi ke sekolah, menarik diri dari pergaulan, kesulitan untuk berkonsentrasi saat belajar sehingga menyebabkan prestasi akademiknya menurun, dan fatalnya korban memiliki keinginan untuk bunuh diri daripada harus menghadapi tekanan-tekanan berupa hinaan dan hukuman. Selain itu berdasarkan wawancara awal yang dilakukan oleh peneliti kepada seorang guru Sekolah Dasar dikatakan bahwa anak yang menjadi korban bullying biasanya memiliki prestasi dalam rentang menengah ke bawah. Beliau mengatakan hal tersebut dikarenakan anak menjadi kurang berkonsentrasi dalam mengikuti pelajaran sehingga pelajaran yang ia peroleh tidak maksimal masuk ke dalam otaknya (FN3L6).

Fenomena lain terkait kasus bullying terjadi khususnya di kalangan anak Sekolah Dasar juga dipengaruhi oleh proses modeling, yang mereka peroleh dari media elektronik (televisi). Menurut Tinsey (dalam Hughes, 2002) televisi memiliki potensi dalam memunculkan perilaku yang membahayakan bagi anak. Tayangan sinetron yang sering mempertontonkan tindakan bullying seperti kekerasan atau kebencian yang dikarenakan status sosial seperti orang kaya yang benci dengan orang miskin atau geng gaul yang suka mengejek anak yang mereka anggap ketinggalan jaman dan sebagainya. Anak-anak dapat melihat adegan kekerasan di televisi, dan jika tidak memperoleh perhatian dan pendampingan penuh dari orang tua, maka anak akan cenderung untuk meniru adegan kekerasan yang dilihatnya.
Erikson (dalam Santrock, 2011) menjelaskan anak usia Sekolah Dasar berada pada tahap industry vs inferiority yang pada tahap ini anak sudah memasuki dunia sekolah. Pada tahap ini dapat dikatakan anak memiliki jiwa kompetitif yang tinggi dan berfokus pada pencapaian prestasi dan anak akan berusaha semaksimal mungkin agar dapat lebih unggul dibanding teman-temannya. Jiwa kompetitif pada anak menurut Rigby (2007) dapat menimbulkan adanya tindakan bullying pemenang dalam suatu kegiatan kompetitif sering kali memunculkan sikap arogansinya dengan menindas temannya yang kurang mampu.

Prestasi belajar merupakan suatu yang penting untuk dicapai oleh siswa dalam suatu pembelajaran. Prestasi belajar merupakan tingkat keberhasilan dalam suatu proses belajar yang dinyatakan dalam bentuk nilai atau raport. Siswa diharapkan untuk mencapai suatu prestasi belajar yang baik sebagai bukti dari suatu keberhasilan belajar. Namun pada kenyataannya tidak semua siswa mampu mencapai suatu prestasi belajar yang baik karena terdapat banyak kendala yang dihadapi oleh siswa.

Beberapa tokoh mendefinisikan prestasi belajar sebagai hasil yang diperoleh oleh siswa terkait dengan proses belajarnya (Hapsari, 2005; Olivia, 2008; Akbar, 2008; Sudijono, 2009; Hamdu \& Agustina, 2011; Wardiyati, 2006; Safura \& Supriyanti, 2006; Ghufron, 2012). Namun hanya beberapa yang memaparkan prestasi belajar yang dapat dinyatakan dalam nilai raport (Hamdu \& Agustina, 2011). Oleh karena itu peneliti menyimpulkan definisi prestasi belajar berdasarkan definisi dikemukakan oleh Hapsari (2005), Ghufron (2012), Sudijono (2009), Hamdu dan Agustini (2011) sebagai penilaian pada hasil belajar yang diperoleh oleh siswa yang dinyatakan dalam bentuk simbol angka, maupun kalimat pada periode tertentu atau dinyatakan dalam bentuk nilai raport. Hal ini menjadi fokus penelitian ini oleh karena relevan dengan konteks nilai raport yang akan digunakan dalam mengukur prestasi belajar siswa.

Penelitian yang dilakukan oleh Septrina, Liow, Sulistiyawati dan Andriani (2009) yang menghasilkan bahwa terdapat hubungan negatif yang signifikan antara self esteem dengan bullying, jika self esteem tinggi maka bullying akan semakin rendah dan jika self esteem rendah maka bullying yang terjadi akan semakin tinggi. Erikson (dalam Santrock, 2009) memaparkan bahwa penting bagi anak untuk memperoleh penghargaan pada tahap industry vs inferiority dan hal tersebut akan berkaitan dengan self esteem. Apabila anak tidak memperoleh penghargaan dari orang lain pada masa industry vs inferiority maka akan mengakibatkan self esteem anak tersebut rendah atau menimbulkan perasaan rendah diri pada anak. Perasaan rendah diri pada anak tersebut akan mempengaruhi aspek prestasi pada siswa (Schunk dalam Santrock, 2011). Dalam pandangannya, perasaan rendah diri pada anak akan menyebabkan anak menghindari banyak tugas 
atas pembelajaran khususnya proses pembelajaran yang lebih kompleks. Begitu pula halnya apabila dalam fase ini anak mengalami tekanan di sekolah seperti tindakan bullying, apakah ada kemungkinan anak tersebut tetap dapat mencapai prestasinya dengan baik? Oleh karena itu peneliti ingin mengetahui apakah ada hubungan antara tindakan bullying dengan prestasi belajar anak korban bullying pada tingkat Sekolah Dasar. Manfaat praktis dari penelitian ini adalah diharapkan dapat memberikan informasi tentang tindakan bullying sehingga tenaga pendidik dapat menciptakan suasana kondusif di sekolah untuk mengurangi tindakan bullying yang terjadi di sekolah. Bagi orang tua diharapkan penelitian ini dapat digunakan menjadi acuan untuk mengetahui dampak tindakan bullying yang terjadi pada anak korban bullying sehingga nantinya orang tua dapat mendengarkan keluh kesah yang dialami anak korban bullying serta melaporkan tindakan bullying yang dialami oleh anak kepada pihak sekolah agar tindakan bullying yang dialami tersebut tidak berkelanjutan. Bagi pihak sekolah penelitian ini dapat memberikan informasi terkait tindakan bullying dan efeknya terhadap korban bullying. Sehingga nantinya pihak sekolah lebih menentapkan aturan-aturan terkait dengan tindakan bullying di seluruh lingkungan sekolah.

\section{METODE}

\section{Variabel dan definisi operasional}

Sugiyono (2003) variabel merupakan segala sesuatu yang berbentuk apa saja yang ditetapkan oleh peneliti untuk dipelajari sehingga diperoleh informasi tentang hal tersebut, kemudian ditarik kesimpulannya. Menurut Sugiyono (2003) variabel independen (bebas) adalah variabel yang mempengaruhi atau yang menjadi sebab perubahannya atau timbulnya variabel dependen (terikat). Variabel dependen menurut Sugiyono (2003) merupakan variabel yang dipengaruhi atau yang menjadi akibat karena adanya variabel independen. Tindakan bullying dalam penelitian ini berperan sebagai variabel independen dan prestasi belajar dalam penelitian ini berperan sebagai variabel dependen.

Definisi dari tindakan bullying pada penelitian ini adalah tindakan menekan atau mengintimidasi yang dialami anak korban bullying baik secara fisik maupun verbal yang dilakukan secara berulang dan biasanya terjadi ketidakseimbangan kekuasaan antara pelaku dan korban bullying. Penelitian ini menggunakan tipe-tipe tindakan bullying yang dimodifikasi dari tipe-tipe yang dikemukakan oleh Field (2007) sesuai dengan konteks yang terjadi di kalangan Sekolah Dasar yaitu teasing (sindiran), exclusion (pengeluaran), physical (fisik) dan harassment (gangguan).
Definisi operasional dari variabel prestasi belajar yaitu penilaian pada hasil belajar yang diperoleh oleh siswa yang dinyatakan dalam bentuk simbol angka maupun kalimat pada periode tertentu atau dapat dinyatakan dalam nilai raport. Prestasi belajar dalam penelitian ini akan diukur berdasarkan nilai total yang diperoleh siswa korban bullying yang tercantum dalam nilai raport semester ganjil.

\section{Responden}

Sugiyono (2003) populasi merupakan wilayah generalisasi yang terdiri atas objek/subjek yang mempunyai kualitas dan karakteristik tertentu yang ditetapkan oleh peneliti untuk dipelajari dan kemudian ditarik kesimpulannya. Populasi dalam penelitian ini adalah siswa dan siswi Sekolah Dasar di Bali. Berdasarkan data dari Badan Akreditasi Nasional Sekolah/Madrasah Provinsi Bali (2013) jumlah Sekolah Dasar Negeri di Bali adalah 1.000 sekolah. Karakteristik sampel pada penelitian ini adalah responden merupakan siswa dan siswi Sekolah Dasar yang sedang duduk di kelas 4, 5 dan 6 yang pernah mengalami beberapa bentuk tindakan bullying.

Metode pengambilan sampel yang digunakan dalam penelitian ini adalah cluster sampling yaitu teknik yang digunakan untuk menentukan sampel jika sumber yang diteliti sangat luas yaitu Provinsi Bali (Sugiyono, 2003). Teknik sampel ini digunakan melalui dua tahap, yaitu tahap pertama untuk menentukan sampel daerah yaitu dengan melakukan pengundian untuk menentukan kabupaten yang akan digunakan sebagai lokasi penelitian sehingga diperoleh hasil yaitu Kabupaten Badung, Kabupaten Gianyar dan Kota Denpasar. Tahap kedua yaitu menentukan subjek yang digunakan dalam penelitian ini. Untuk menentukan subjek penelitian ini, peneliti kemudian menggunakan purposive sampling yaitu memilih sekelompok subjek didasarkan atas ciri atau sifat tertentu yang dipandang mempunyai sangkut paut yang erat dengan ciri atau sifat populasi yang sudah diketahui sebelumnya (Sugiyono, 2003).

\section{Tempat penelitian}

Berdasarkan hasil pengundian secara acak pada 8 kabupaten yang ada di Bali, diperoleh hasil yaitu lokasi penelitian ini adalah bertempat di Kabupaten Badung, Kabupaten Gianyar dan Kota Denpasar. Jumlah sampel yang digunakan dalam penelitian ini diperoleh dengan menggunakan rumus Higgins, Kleinbaum dan Miller (1985) yaitu berdasarkan rumus populasi yang tidak diketahui karena sepengetahuan peneliti belum ada data yang menunjukkan secara pasti jumlah anak yang menjadi korban bullying. Hasilnya adalah jumlah sampel minimal dalam penelitian ini adalah 169 sampel. 


\section{Alat ukur}

Skala pengukuran tindakan bullying dalam penelitian adalah skala tindakan bullying dengan menggunakan tipe-tipe tindakan bullying menurut Field (2007) yang berbentuk skala likert. Skala ini terdiri dari 88 item. Alat ukur yang digunakan untuk mengukur pretasi belajar adalah nilai total pada raport semester ganjil pada tahun 2012.

\section{Metode pengumpulan data}

Penelitian ini merupakan cross sectional study yang menurut Sugiyono (2003) memiliki definisi yaitu penelitian yang mempelajari obyek riset dalam suatu waktu tertentu saja (tidak berkesinambungan dalam waktu panjang). Jadi penelitian ini hanya meneliti tindakan bullying yang dialami oleh korban bullying pada saat penelitian ini dilakukan dan hanya melihat nilai raport korban bullying pada saat penelitian berlangsung. Metode pengumpulan data yang digunakan dalam penelitian ini adalah dengan menggunakan 1 kuisioner yaitu kuisioner tindakan bullying yang disusun sendiri oleh peneliti berdasarkan tipe-tipe tindakan bullying yang dikemukakan oleh Field (2007). Kuisioner ini terdiri dari empat pilihan jawaban yaitu "sangat setuju", "setuju", "tidak setuju", dan "sangat tidak setuju". Sedangkan untuk variabel prestasi belajar sendiri diukur dengan menggunakan nilai total pada raport semester ganjil tahun 2012.

\section{Teknik analisis data}

Priyatno (2012) mengungkapkan bahwa uji validitas digunakan untuk mengetahui seberapa cermat instrumen dalam mengukur apa yang hendak diukur. Sugiyono (2003) validitas terbagi menjadi tiga jenis yaitu validitas konstruk, validitas isi dan validitas eksternal. Peneliti melakukan pengujian pada validitas konstruk dan validitas isi dalam penelitian ini. Validitas konstruk merupakan validitas yang mengungkap sejauh mana tes mengungkap suatu trait atau konstrak teoritik yang diukurnya (Allen \& Yen dalam Azwar, 2010). Validitas konstruk pada penelitian ini akan di ukur dengan perhitungan item-item yang menggunakan tabel korelasi product moment. Nurgiyantoro, Gunawan dan Marzuki (2004) menyatakan item dikatakan valid apabila $r$ hitung lebih besar dari pada $r$ table. Validitas isi menurut Azwar (2010) merupakan validitas yang diestimasi lewat pengujian terhadap isi tes dengan analisis rasional atau lewat professional judgment dalam artian sejauh mana item-item dalam tes mencakup keseluruhan kawasan isi objek yang hendak diukur atau sejauhmana isi tes mencerminkan ciri atribut yang hendak diukur.
Uji reliabilitas digunakan untuk melihat konsistensi alat ukur, yang artinya apakah hasil pengukuran suatu alat ukur tetap konsisten jika pengukuran diulang (Priyatno, 2012). Reliabilitas memiliki berbagai nama lain seperti keterpercayaan, keterandalan, keajegan, kestabilan, konsistensi. Estimasi terhadap reliabilitas hasil pengukuran tes pada penelitian ini dilakukan dengan menggunakan metode estimasi penyajian tunggal (single trial administration) yang menghasilkan koefisien konsistensi internal. Pada penelitian ini uji reliabilitas dibantu dengan menggunakan SPSS 16. Suatu alat ukur dinyatakan memiliki reliabilitas yang baik apabila skor koefisien alfa lebih besar dari 0,6.

Metode analisis data yang digunakan dalam penelitian ini adalah analisis regresi linier sederhana. Gulo (2003) menjelaskan analisis regresi merupakan analisis yang mengukur hubungan fungsional antara dua variabel atau lebih. Metode ini digunakan untuk menentukan bentuk hubungan antara bullying dengan prestasi belajar, serta untuk melihat besarnya sumbangan variabel bullying terhadap prestasi belajar. Namun sebelum melakukan analisis data perlu dilakukan uji asumsi berupa uji normalitas dan uji linieritas sebagai syarat dalam penggunaan analisis regresi liner sederhana. Sugiyono (2003) mengungkapkan bahwa pengujian normalitas dilakukan untuk mengetahui apakah variabel yang akan dianalisis berdistribusi normal. Uji normalitas dalam penelitian ini menggunakan menggunakan teknik Kolmogorov-Smirnov Goodness of Fit Test. Data yang diperoleh dikatakan berdistribusi normal menurut Nurgiyantoro, Gunawan dan Marzuki (2004) jika nilai P lebih besar dari 0.05. Dalam penelitian ini, uji linieritas dilakukan untuk mengetahui apakah terdapat hubungan yang linier antara kedua variabel penelitian. Adanya hubungan yang linier akan menunujukkan bahwa perubahan pada variabel prediktor cenderung diikuti oleh perubahan variabel kriterium dengan membentuk garis linier (Sugiyono, 2003). Uji Linieritas dalam penelitian ini menggunanakan bantuan komputasi SPSS 16 yaitu compare means. Uji ini menunjukkan penyimpangan dari model linier. Jika hasil analisis uji linieritas memperoleh nilai $\mathrm{P}$ lebih besar atau sama dengan 0.05 maka menandakan ada hubungan linier antara kedua variabel (Nurgiyantoro, Gunawan \& Marzuki, 2004).

\section{HASIL PENELITIAN}

Uji coba alat ukur dalam penelitian ini dilakukan terhadap responden penelitian, yaitu siswa dan siswi Sekolah Dasar di Kabupaten Badung, Kabupaten Gianyar dan Kota Denpasar yang merupakan korban bullying dan dilaksanakan pada bulan Desember 2012 sampai Januari 2013. Uji coba penelitian ini dilakukan dengan menyebarkan kuisioner kepada 176 orang responden yang awalnya terdiri dari 88 item. Data yang telah diperoleh pada saat melakukan uji coba 
alat ukur penelitian akan dianalisis untuk mengetahui validitas dan reliabilitasnya. Berdasarkan uji yang telah dilakukan diperoleh hasil yaitu koefisien korelasi dalam skala tindakan bullying bergerak dari -0.016 sampai 0.611. Jumlah item yang gugur pada uji ini adalah 14 item. Setelah item yang gugur dikeluarkan (dibuang) kemudian diuji kembali diperoleh hasil koefisien korelasi berkisar dari 0.204 sampai 0.646. Jumlah item gugur dalam skala tindakan bullying adalah 14 item dari 88 item, sehingga item yang tersisa berjumlah 74 item.

Reliabilitas yang diperoleh dapat dilihat dari koefisien alfa $(\alpha)$ pada skala tindakan bullying. Hasil koefisien alfa $(\alpha)$ adalah 0.926 dengan jumlah subjeknya sebanyak 176 orang dan jumlah item sebanyak 88 item. Namun dilakukan pengujian kembali karena terdapat beberapa item yang tidak memenuhi kriteria sehingga harus digugurkan. Koefisien alfa ( $\alpha$ ) yang diperoleh sebesar 0.936. Hasil koefisien alfa yang diperoleh sudah mendekati 1 sehingga skala tersebut dapat dikatakan layak digunakan dalam penelitian dan dapat mengukur dengan baik aspek-aspek yang ingin peneliti ungkap.

Hasil dari uji normalitas yang diperoleh kedua data tersebut dapat dikatakan normal karena $\mathrm{P}$ yang diperoleh lebih besar dari 0.05 variabel bullying menghasilkan kolmogorov smirnov sebesar 0.646 dan P sebesar 0.798 (P lebih besar dari 0.05) dan variabel prestasi belajar menghasilkan kolmogorov smirnov sebesar 1.097 dan P sebesar 0.180 (P lebih besar dari 0.05). Data ini dikatakan normal sehingga data tersebut dianggap dapat mewakili populasi. Uji asumsi berikutnya yaitu uji linieritas menunjukkan hasil yaitu $\mathrm{P}=0.000$ ( $\mathrm{P}$ lebih besar dari 0.05) yang artinya data yang digunakan dalam penelitian ini adalah linier. Linier berarti data membentuk garis lurus sehingga dapat dilihat hubungannya. Jadi dapat dikatakan variabel tindakan bullying dapat menyebabkan variabel prestasi belajar atau sebaliknya.

Setelah kedua syarat untuk melakukan analisis data telah dipenuhi, dilanjutkan dengan menggunakan metode analisis regresi linier sederhana dengan bantuan SPSS 16.00.

Tabel 1

Hasil Uji Regresi Linier Sederhana

\begin{tabular}{|c|c|c|c|c|c|}
\hline $\begin{array}{l}\text { Variabel } \\
\text { Terikat }\end{array}$ & Variabel Bebas & $\begin{array}{l}\text { Koefisien } \\
\text { Regresi }\end{array}$ & $t$ hitung & Sig. & $t_{\text {tabel }}$ \\
\hline $\begin{array}{l}\text { Prestasi } \\
\text { Belajar (Y) }\end{array}$ & Bullying & -1.698 & -16.388 & 0.000 & \pm 1.645 \\
\hline $\begin{array}{l}\text { Constant } \\
\mathrm{R} \\
\mathrm{R} \text { Square } \\
\end{array}$ & $\begin{array}{l}=1126.754 \\
=-0.779 \\
=0.607\end{array}$ & & $\begin{array}{l}\text { F Ratio } \\
\text { Sig. }\end{array}$ & & $\begin{array}{l}=268.571 \\
=0.000\end{array}$ \\
\hline
\end{tabular}

Tabel di atas menunjukkan bahwa nilai thitung lebih besar jika dibandingkan dengan ttabel dan nilai signifikansinya menunjukkan bahwa $\mathrm{P}$ lebih kecil dari 0.05 yang artinya hipotesis alternatif (Ha) diterima yaitu ada hubungan antara tindakan bullying dengan prestasi belajar anak korban bullying pada tingkat Sekolah Dasar. Nilai koefisien korelasi (r) sebesar -0.779 menunjukkan adanya hubungan yang kuat antara variabel tindakan bullying dan variabel prestasi belajar. Sedangkan tanda negatif (-) menunjukkan bahwa semakin tinggi tindakan bullying yang diterima oleh korban bullying maka akan mengakibatkan semakin rendah prestasi belajar. Koefisien determinasi dalam uji ini menunjukkan angka sebesar 0.607, koefisien determinasi menunjukkan seberapa besar sumbangan yang dapat diberikan oleh variabel independen kepada variabel dependen. Dalam penelitian ini sumbangan variabel tidakan bullying kepada variabel prestasi belajar sebesar $60.7 \%$, sedangkan untuk $39.3 \%$ disumbangkan oleh faktor lain kepada prestasi belajar. Persamaan garis regresi menunjukkan bahwa $\mathrm{Y}=\mathrm{a}+\mathrm{bX}$ sehingga diperoleh $\mathrm{Y}=1126.754$ 1.698X. Persamaan ini memiliki arti setiap penambahan satu nilai pada variabel tindakan bullying maka akan menyebabkan penurunan pada variabel prestasi belajar. Nilai pendugaan regresi sebesar -1.698 menunjukkan besaran pengaruh variabel tindakan bullying dengan prestasi belajar.

Berdasarkan hasil pengkategorisasian diperoleh hasil bahwa rata-rata subjek berada pada kategori rendah dalam tindakan bullying dan dalam kategori sedang dalam prestasi belajar yang diperoleh.

\section{PEMBAHASAN DAN KESIMPULAN}

Berdasarkan hasil analisis hubungan dengan menggunakan uji regresi linier sederhana yang dilakukan dalam penelitian ini memberikan hasil yaitu nilai signifikansi (P lebih kecil dari 0.05) dan ttabel lebih besar dari t hitung (16.388 lebih besar dari \pm 1.645 ), hal ini menunjukkan bahwa terdapat antara tindakan bullying dengan prestasi belajar anak korban bullying dapat diterima atau dapat disimpulkan bahwa hipotesis alternatif (Ha) yang diajukan dalam penelitian ini dapat diterima. Nilai rata-rata kelompok kelas dari semua sekolah yang digunakan dalam penelitian terkait dengan prestasi belajar menunjukkan angka yaitu 856.827 , sedangkan nilai rata-rata prestasi belajar subjek dalam penelitian ini adalah sebesar 849.300. Dapat dilihat bahwa nilai rata-rata kelompok lebih besar dari pada nilai rata-rata subjek penelitian, sehingga dapat dikatakan bahwa nilai rata-rata subjek penelitian tergolong rendah jika dibandingkan dengan nilai rata-rata kelompok. Jadi memang terlihat anak yang menjadi korban bullying memiliki prestasi belajar yang rendah jika dibandingkan dengan anak yang tidak menjadi korban bullying.

Koefisien korelasi dalam penelitian ini adalah sebesar -0.779 yang menunjukkan ada hubungan negatif antara tindakan bullying dengan prestasi belajar anak korban bullying pada tingkat Sekolah Dasar dan hubungan tersebut bersifat kuat. Sejalan dengan hasil tersebut, pada kategorisasi yang dilakukan oleh peneliti pada skor subjek pada variabel 
tindakan bullying dan variabel prestasi belajar diperoleh hasil yaitu pada variabel tindakan bullying rata-rata subjek berada pada kategori rendah dan pada variabel prestasi belajar ratarata subjek berada pada kategori sedang. Berdasarkan hasil tersebut dapat disimpulkan bahwa rata-rata subjek mengalami tindakan bullying pada kategori rendah sehingga dapat menyebabkan rata-rata subjek memperoleh prestasi belajar dalam kategori sedang.

Hasil dari penelitian ini didukung oleh pendapat Christin (2009) yang mengatakan bahwa tindakan bullying akan memberikan efek negatif bagi korbannya baik secara fisik maupun psikologis. Rigby (2007) mengatakan bahwa anak yang menjadi korban bullying akan mengalami kesulitan dalam bergaul, merasa takut datang ke sekolah sehingga absensi mereka tinggi dan tertinggal pelajaran, dan mengalami kesulitan berkonsentrasi dalam mengikuti pelajaran sehingga akan mempengaruhi prestasi belajar yang akan dicapai anak tersebut. Seperti yang dikemukakan oleh Hakim (2000) konsentrasi merupakan salah satu faktor penentu keberhasilan belajar siswa. Jadi ketika suatu tindakan bullying tersebut mengakibatkan anak korban bullying mengalami kesulitan berkonsentrasi, maka hal tersebut akan berpengaruh pada prestasi belajar yang akan diperoleh.

Wiyani (2012) mengungkapkan bahwa bullying adalah suatu isu yang tidak semestinya dipandang sebelah mata dan diremehkan, bahkan disangkal keberadaannya. Siswa-siswa yang menjadi korban dari bullying akan menghabiskan banyak waktu untuk memikirkan berbagai cara untuk menghindari gangguan di sekolah sehingga mereka hanya memiliki sedikit energi untuk belajar. Hal inilah yang akan mempengaruhi prestasi belajar yang akan dicapai oleh siswa. Trigg (dalam Siswati \& Widayanti, 2009) juga mendukung hasil penelitian ini, korban bullying memiliki penyesuaian sosial yang buruk korban merasa takut ke sekolah bahkan tidak mau sekolah, menarik diri dari pergaulan, prestasi akademik yang menurun karena mengalami kesulitan untuk berkonsentrasi dalam belajar bahkan buruknya korban memiliki keinginan untuk bunuh diri daripada harus menghadapi tekanan-tekanan berupa hinaan dan hukuman.

Variabel tindakan bullying dalam penelitian ini memberikan sumbangan pada prestasi belajar sebesar $60.7 \%$ sedangkan sisanya yaitu $39.3 \%$ disumbangkan pada variabel lain. Faktor lain yang mempengaruhi prestasi belajar seperti yang diungkapkan oleh Hakim (2000) seperti yang telah dibahas pada Bab II mengungkapkan bahwa ada faktor lain yang mempengaruhi prestasi belajar atau keberhasilan belajar selain tindakan bullying yaitu faktor internal dan faktor eksternal individu. Faktor internal individu meliputi faktor biologis dan faktor psikologis. Faktor biologis yang termasuk di dalamnya adalah kondisi fisik yang normal (tidak cacat) dan kondisi fisik yang sehat dan segar. Sedangkan faktor psikologis yang mempengaruhi keberhasilan belajar ini meliputi segala hal yang berkaitan dengan kondisi mental seseorang yang mantap dan stabil meliputi intelegensi atau tingkat kecerdasan dasar, kemauan, bakat, daya ingat dan konsentrasi.

Faktor kedua yaitu faktor eksternal yaitu mempengaruhi faktor lingkungan keluarga, faktor lingkungan sekolah, faktor lingkungan masyarakat dan faktor waktu. Afida (2007) menyebutkan dari hasil penelitiannya bahwa prestasi belajar dipengaruhi oleh kebiasaan belajar. Berdasarkan penelitian tersebut dapat diartikan bahwa siswa memiliki kebiasaan belajar yang baik maka prestasi belajarnya juga akan baik, atau dengan kata lain semakin baik kebiasaan belajar yang dilakukan oleh siswa maka semakin tinggi pula prestasi belajar yang diperoleh oleh siswa. Selain itu penelitian yang dilakukan oleh Setiadi (2001) memperoleh hasil bahwa terdapat hubungan bermakna antara inteligensi (IQ) dengan prestasi belajar. Namun hasil selanjutnya menunjukkan bahwa tidak terdapat hubungan bermakna antara status gizi dan lingkungan belajar dengan prestasi belajar siswa.

Tindakan bullying yang dialami oleh anak korban bullying akan berdampak pada prestasi belajar yang diperoleh oleh anak korban bullying karena korban bullying akan mengalami kesulitan berkonsentrasi dan sering absen ke sekolah yang merupakan aspek yang menentukan keberhasilan belajar siswa. Hasil yang diperoleh dari pernyataan-pernyataan dari kuisioner menggambarkan bahwa korban bullying merasa sedih ketika pelaku melakukan tindakan bullying kepadanya, korban juga merasa takut untuk pergi ke sekolah, dan korban merasa tidak berkonsentrasi dalam mengikuti pelajaran karena tindakan bullying yang diterimanya tersebut.

Selain untuk menjawab hipotesis, peneliti melakukan analisis tambahan untuk mengetahui aspek tindakan bullying yang lebih mempengaruhi variabel prestasi belajar. Variabel tindakan bullying dalam penelitian ini dibagi menjadi 4 aspek berdasarkan yang bentuk-bentuk tindakan bullying yang dikemukakan oleh Field (2007). Aspek- aspek tersebut yaitu teasing (sindiran), exclusion (pengeluaran), physical (fisik), harassment (gangguan). Untuk mengetahuinya peneliti melakukan analisis melalui program SPSS 16 untuk mengkorelasikan masing-masing aspek dengan prestasi belajar. Hasilnya akan dijabarkan pada tabel berikut ini:

$$
\text { Tabel } 19 .
$$

Analisis Aspek Tindakan Bullying

\begin{tabular}{lll}
\hline Aspek & $\mathrm{P}$ & $\mathrm{R}$ \\
\hline Teasing & $0.003(\mathrm{P}<0.05)$ & -0.222 \\
\hline Exclusion & $0.000(\mathrm{P}<0.05)$ & -0.306 \\
\hline Physical & $0.013(\mathrm{P}<0.05)$ & -0.188 \\
\hline Harassment & $0.000(\mathrm{P}<0.05)$ & -0.273 \\
\hline
\end{tabular}

Aspek yang paling mempengaruhi prestasi belajar adalah exclusion (pengeluaran) yaitu sebesar -0.306. Hal ini sesuai dengan hasil penelitian yang dilakukan oleh Yayasan Semai Jiwa Amini (dalam Wiyani, 2012) tentang kekerasan bullying di tiga kota besar di Indonesia yaitu Yogyakarta, 
Surabaya, dan Jakarta. Hasil dari penelitian ini adalah tercatat bahwa telah terjadi tindak kekerasan sebesar $66.1 \%$ pada tingkat SMA dan 41.2\% pada tingkat SMP. Pada tingkat SMA kategori tertinggi dari jenis kekerasan yang dialami oleh korbannya adalah kekerasan psikologis berupa pengucilan atau pengeluaran, peringkat kedua ditempati oleh kekerasan verbal (mengejek) dan terakhir oleh kekerasan fisik (memukul). Nantinya jenis kekerasan ini akan memberikan dampak negatif bagi korbannya yang nantinya akan berdampak pada prestasi belajar yang diperoleh oleh anak korban bullying.

Berdasarkan hasil analisis yang telah dilakukan diperoleh hasil bahwa tindakan bullying yang paling sering terjadi pada anak Sekolah Dasar adalah berupa exclusion (pengeluaran) seperti mengucilkan korban secara sosial seperti tidak mengajak korban berbicara, berpura-pura bersikap ramah pada korban namun secara sporadis melakukan tindakan bullying pada korban, mendiamkan korban atau mengacuhkan korban, menunjuk korban sambil tertawa dan menunjuk, menunjukkan gerakan mengancam, tidak mengikutsertakan korban pada percakapan maupun permainan, menyebarkan gosip pada korban dan memberikan ancaman. Untuk lebih jelasnya akan disajikan tabel yang menunjukkan persentase jumlah subjek pada masing-masing aspek berdasarkan jenis kelamin:

Tabel 20.

Persentase Subjek Laki-Laki dan Perempuan pada Masing-Masing Aspek

\begin{tabular}{llll}
\hline \multirow{2}{*}{ Teasing } & \multirow{2}{*}{ Aspek } & \multicolumn{2}{c}{ Jenis kelamin } \\
\cline { 2 - 4 } & & Tali-lahi & Perempuan \\
\cline { 2 - 4 } & Singgi & $40 \%$ & $60 \%$ \\
\cline { 2 - 4 } & Sedang & $52.6 \%$ & $48.4 \%$ \\
\hline Exclusion & Tinggi & $64.3 \%$ & $35.7 \%$ \\
\cline { 2 - 4 } & Sedang & $42.9 \%$ & $57.1 \%$ \\
\cline { 2 - 4 } & Rendah & $55.7 \%$ & $44.3 \%$ \\
\hline Physical & Tinggi & $40 \%$ & $60 \%$ \\
\cline { 2 - 4 } & Sedang & $58.5 \%$ & $41.5 \%$ \\
\cline { 2 - 4 } & Rendah & $48.8 \%$ & $51.2 \%$ \\
\hline Harassment & Tinggi & $66.7 \%$ & $33.3 \%$ \\
\cline { 2 - 4 } & Sedang & $25 \%$ & $75 \%$ \\
\cline { 2 - 4 } & Rendah & $56.8 \%$ & $43.2 \%$ \\
\hline
\end{tabular}

Tabel di atas menunjukkan bahwa terdapat perbedaan tindakan bullying yang diterima oleh subjek laki-laki maupun perempuan. Jika dilihat pada kategori tinggi untuk masingmasing aspeknya maka subjek laki-laki lebih banyak mengalami tindakan bullying pada aspek physical, sedangkan untuk ketiga aspek lainnya yaitu teasing, exclusion dan harassment lebih didominasi oleh subjek perempuan. Subjek laki-laki dalam penelitian ini mengalami tindakan bullying berupa tendangan, cubitan, dorongan, menjambak rambut, pukulan, barang-barang yang dicuri dan dilempar, dan dipaksa untuk memberikan pekerjaan rumah. Subjek perempuan dalam penelitian ini mengalami tindakan bullying berupa verbal, dikucilkan dari lingkungan sosial, menjadi bahan pergunjingan atau gosip, dan gangguan atau penyerangan terkait masalah seksual. Hasil dari penelitian ini didukung oleh penelitian yang dilakukan oleh Siswati dan Widayanti (2009) yang menunjukkan bahwa memang terdapat perbedaan perilaku bullying yang dialami oleh laki-laki maupun perempuan.

Karakteristik responden dalam penelitian ini yaitu laki-laki berjumlah 90 orang dan perempuan berjumlah 86 orang. Hal ini sejalan dengan hasil penelitian yang dilakukan oleh Hertinjung, Susilowati dan Wardani (2012) jumlah korban bullying didominasi oleh laki-laki dibandingkan perempuan. Sedangkan karakteristik responden dalam penelitian ini berdasarkan kelas adalah 41 orang berada di kelas 4, 60 orang berada di kelas 5 dan 75 orang berada di kelas 6 . Karakteristik responden jika dilihat dari jenis kelamin pada masing-masing kelas adalah laki-laki pada kelas 4 sejumlah 21 orang, subjek perempuan pada kelas 4 sejumlah 20 orang, subjek laki-laki pada kelas 5 sejumlah 28 orang, subjek perempuan pada kelas 5 sejumlah 32 orang, subjek laki-laki pada kelas 6 sejumlah 41 orang dan subjek perempuan pada kelas 6 sejumlah 34 orang. Dari data di atas terlihat bahwa korban bullying didominasi oleh laki-laki dibandingkan perempuan, walaupun pada kelas 5 korban bullying didominasi oleh perempuan. Namun pada kelas 4 maupun kelas 6 korban bullying didominasi oleh jenis kelamin laki-laki.

Kesimpulan yang dapat diambil berdasarkan penelitian yang telah dilakukan oleh peneliti yaitu terdapat hubungan negatif antara tindakan bullying dengan prestasi belajar anak korban bullying pada tingkat Sekolah Dasar. Semakin tinggi tindakan bullying yang dialami anak korban bullying maka prestasi belajar akan semakin rendah. Begitu pula sebaliknya, semakin rendah tindakan bullying yang dialami oleh korban bullying maka prestasi belajarnya akan semakin tinggi. Hasil ini didukung dengan nilai rata-rata subjek penelitian lebih rendah dibandingkan nilai rata-rata kelompok pada sekolah yang menjadi lokasi penelitian. Hal ini menunjukkan bahwa prestasi belajar anak korban bullying memang lebih rendah dari pada nilai anak yang tidak menjadi korban bullying di sekolah yang bersangkutan. Hasil analisis ini juga menunjukkan bahwa tindakan bullying yang dialami oleh anak korban bullying dapat memprediksi prestasi belajar. Analisis tambahan yang dilakukan peneliti memberikan hasil bahwa keempat aspek tindakan bullying memiliki hubungan negatif dengan prestasi belajar anak korban bullying. Namun dari keempat aspek tersebut, aspek exclusion (pengeluaran) yang memiliki hubungan paling tinggi terhadap prestasi belajar yang artinya korban bullying pada penelitian ini kebanyakan subjek mengalami tindakan bullying berupa exclusion (pengeluaran). Tindakan tersebut berupa mengucilkan korban secara sosial seperti tidak mengajak korban berbicara, berpura-pura bersikap ramah pada korban namun secara sporadis melakukan tindakan bullying pada korban, mendiamkan korban atau mengacuhkan korban, menunjuk korban sambil tertawa dan menunjuk, menunjukkan gerakan mengancam, tidak mengikutsertakan korban pada 
percakapan maupun permainan, menyebarkan gosip pada korban dan memberikan ancaman (Field, 2007).

Korban bullying dalam penelitian ini lebih didominasi oleh jenis kelamin laki-laki dibandingkan perempuan. Terdapat perbedaan tindakan bullying yang dialami oleh korban lakilaki dan perempuan dan hasil ini sesuai dengan penelitian yang dilakukan oleh Christin (2009). Subjek laki-laki dalam penelitian ini mengalami tindakan bullying berupa tendangan, cubitan, dorongan, menjambak rambut, pukulan, barangbarang yang dicuri dan dilempar, dan dipaksa untuk memberikan pekerjaan rumah. Subjek perempuan dalam penelitian ini mengalami tindakan bullying berupa verbal, dikucilkan dari lingkungan sosial, menjadi bahan pergunjingan atau gosip, dan gangguan atau penyerangan terkait masalah seksual

Saran praktis yang ditawarkan oleh peneliti kepada pihak sekolah adalah lebih memperhatikan tindakan bullying yang terjadi di sekolah dan meningkatkan pemahaman tentang apa itu tindakan bullying. Dalam mengurangi terjadinya tindakan bullying di sekolah, pihak sekolah dapat menerapkan program peaceful school yaitu program untuk menciptakan sekolah yang aman dan nyaman karena setiap komponen sekolah memiliki rasa kasih sayang, perhatian, kepercayaan, dan kenyamanan (Wiyani, 2012). Pihak sekolah juga sebaiknya mengadakan pertemuan secara berkala dengan orang tua terkait dengan isu kekerasan yang terjadi di kalangan siswa. Hal ini dilakukan agar orang tua juga mengetahui tentang perkembangan anak-anak mereka di sekolah sehingga guru dan orang tua dapat bersama-sama meningkatkan perhatian terhadap isu kekerasan tersebut. Bagi orang tua lebih meluangkan waktu dalam memperhatikan aktivitas yang dilakukan oleh anak. Orang tua juga sebaiknya meluangkan waktu untuk mendengarkan keluh kesah anak dan sebaiknya orang tua segera melaporkan tindakan bullying yang terjadi pada anaknya sehingga pihak sekolah dapat menindaklanjuti hal tersebut. Saran bagi penelitian selanjutnya adalah lebih mengontrol variabel lain yang mempengaruhi prestasi belajar. Peneliti juga sebaiknya mendampingi subjek ketika mengisi skala penelitian sehingga subjek mengertikan apa maksud dari skala yang diberikan tersebut. Selain itu penelitian yang berkaitan dengan dampak dari tindakan bullying terhadap prestasi belajar sebaiknya dilakukan secara longitudinal, penelitian selanjutnya disarankan untuk menggali fenomena bullying secara lebih mendalam seperti meneliti tindakan bullying yang dialami oleh anak korban bullying dengan metode kualitatif atau dengan menambah metode pengumpulan data baik itu dengan observasi maupun dengan metode self report. Peneliti selanjutnya sebaiknya lebih mengacu pada teori-teori yang lebih baru. Selain itu dalam mengungkap validitas dalam penelitian sebaiknya tidak hanya mengungkap validitas isi dan validitas konstruk saja tapi diperlukan untuk menguji validitas tampak untuk meyakinkan dan memberikan kesan bahwa tes yang disusun mampu mengungkap apa yang hendak diukur. Bagi peneliti selanjutnya diperlukan untuk menyertakan informed consent sebagai tanda bukti bahwa subjek bersedia menjadi subjek penelitian, walaupun dalam pelaksanaannya peneliti telah meminta izin kepada subjek penelitian sebelum memberikan kuisioner penelitian.

\section{DAFTAR PUSTAKA}

Afida, H. (2007). Pengaruh kebiasaan belajar dan minat membaca terhadap prestasi belajar siswa kelas VIII pada materi pelajaran IPS di MTs Darul Huda Wonodadi Blitar. Skripsi. Diakses 15 Februari 2013 dari http://lib.uinmalang.ac.id/thesis/fullchapter/03160031-husna-afida.ps.

Akbar, H., Sihadi, (2011). Akselerasi (A-Z inf program percepatan Belajar). Jakarta: PT Grasindo.

Alika, H.I. (2012). Bullying as a correlate of dropout from school among adolescent. Education, Vol. 132 No. 3. http://www.projectinnovation.biz/education.html.

Anonim. (2012). Begini kronologi tawuran SMA 6 versus SMA 70. Tempo.com. Diakses 24 April 2013 dari http://www.tempo.co/read/news/2012/09/24/064431613/Be gini-Kronologi-Tawuran-siswa-SMA-6-Versus-SMA-70">.

Azwar. (1998). Metodelogi penelitian . Yogyakarta: Pustaka Pelajar Offset.

Badan Akreditasi Nasional Sekolah/Madrasah Provinsi Bali. (2013, April 27). Ban-SM. Diakses 27 April 2013 dari http://www.bansm.or.id/provinsi/bali/akreditasi/index/page: 8 .

Christin. (2009). Dampak psikologis bullying pada siswa SMA. Yogyakarta: Gunadarma University. Diakses November 12, 2012, dari http://www.gunadarma.ac.id.

Down, F. (2012, Juli 29). Stop bullying dan atribut aneh pada MOS (masa orientasi siswa). Kompasiana.com. diakses 24 April 2013 dari http://sosbud.kompasiana.com/2012/07/28/stopbullying-dan-atribut-aneh-pada-masa-orientasi-siswa-mos474797.html>.

Field, E. M. (2007). Bully blocking six secrets to help children. United Kingdom: Jessica Kingsley Publishers.

Ghufron, M., Risnawati, R. (2012). Gaya belajar. Yogyakarta: Pustaka Pelajar.

Glew, Rivara, \& Freudtner. (2000). Children hurting children. Pediatricts $\quad$ Review. 183-190. http://dev.cjcenter.org/_files/cvi/BullyHealthfinal.pdf.

Gulo. (2003). Metodologi penelitian. Jakarta: PT. Grasindo. 
Hakim, T. (2000). Belajar secara efektif. Jakarta: Pustaka Pembangunan Swadaya Nusantara.

Hamdu, G., Agustina, L. (2011). Pengaruh motivasi belajar siswa terhadap prestasi belajar IPA di Sekolah Dasar (studi kasus terhadap siswa Kelas IV SDN Tarumanagara Kecamatan Tawang Kota Tasikmalaya) . Jurnal Penelitian Pendidikan Vol. 12 No. 1. ISSN: 1412-565X 90.

Hapsari, S. (2005). Bimbingan \& konseling SMA kelas XI. Jakarta: PT. Grasindo.

Hertinjung, W. S., Susilowati., \& Wardani, I.R. (2012). Profil kepribadian 16 PF pelaku dan korban bullying. Prosiding Seminar Nasional Psikologi Islami, 190-199. http://publikasiilmiah.ums.ac.id/bitstream/handle/12345678 9/1768/C8.\%20HertinUMS $\% 20 \% 28$ fixed $\% 29$.pdf?sequence $=1$.

Higgins, J. E., Kleinbaum, A. P., \& Miller, P. (1985). Design methodology for randomized clinical trials: Family health international. North Carolina, USA: Research Triangle Park.

Nurgiyantoro, B., Gunawan, \& Marzuki. (2004). Statistik terapan (untuk penelitian ilmu-ilmu sosial). Yogjakarta: Gadjah Mada University Press.

Olivia, F. (2008).Teknik ujian efektif. Jakarta : Elex Media Komputindo.

Priyatno, D. (2012). Belajar cepat olah data statistik dengan SPSS. Yogyakarta : Andi Offset.

Rigby, K. (2007). Bullying in schools. Australia: Acer Press.

Riyana (2009). Membuka selubung kekerasan di sekolah. Kedaulatan Rakyat, 163, LXIV, 15.

Rmol. (2012, Agustus 2). Disdik DKI nggak becus tangani bullying di sekolah. Rmol.co. Diakses pada 24 April 2012 dari http://nusantara.rmol.co/read/2012/08/02/73279/DisdikDKI-Nggak-Becus-Tangani-Bullying-Di-Sekolah- .

Safura.,Supriyanti. (2006). Hubungan antara penyesuaian diri anak di sekolah dengan prestasi belajar. Psikologia Volume 2. http://repository.usu.ac.id/bitstream/123456789/15722/1/psi -jun2006-\%20\%284\%29.pdf.

Sampson, R. (2012). Bullying in school. U.S: COPS.

Santrock, J. W. (2009). Masa perkembangan anak. Jakarta: Salemba Humanika.

Septrina, M. A., Liow, C. J., Sulistiyawati, F. N., \& Andriani, I. (2009). Hubungan tindakan bullying di sekolah dengan self esteem siswa. Proceeding PESAT (Psikologi, ekonomi,
Sastra, Arsitektur, \& Sipil) Vol 3 Oktober 2009. ISSN: $1885-2559$.

Setiadi, D. W. (2001). Hubungan inteligensi, status gizi dengan prestasi belajar siswa SLTP (studi kasus di SLTP 2, SLTP 14 Kotamadia Semarang. Skripsi. Diakses 10 Januari 2013 dari eprints.undip.ac.id/12225/1/2001fk1075.pdf.

Siswati., Widayanti, C. G. (2009). Fenomena bullying di sekolah dasar negeri di semarang. Jurnal Psikologi Undip Vol.5 No.2. fenomena bullying di sekolah dasar negeri di semarang\&source $=$ web $\&$ cd $=1 \&$ cad $=$ rja \&ved $=0 \mathrm{CC} 8 \mathrm{QFjA}$ A\&url=http $\% 3 \mathrm{~A} \% 2 \mathrm{~F} \% 2 \mathrm{Feprints.un}$

Sugiyono. (2003). Metode penelitian administrasi. Bandung: CV. Alfabeta.

Wardiyati, A. (2006). Hubungan antara motivasi dengan prestasi belajar bidang studi pendidikan agama islam. Skripsi. $\begin{array}{lllll}\text { Diakses } & 1 & \text { Oktober } & 2012 & \text { dari }\end{array}$ http://idb4.wikispaces.com/file/view/rc14hubungan+antara+motivasi+denganprestasi+belajar+bidang +studi+pendidikan+agama+islam.pdf

Wiyani, N. A. (2012). Save our children from school bullying. Yogyakarta: AR-RUZZ Media. 